\title{
Financial Crisis, Fall and Financial Theory
}

\section{Dear readers,}

in September, the summer holiday ended, then the time for autumn has began and financial crisis has visited us. On 15th September, 2008 Lehman Brothers Holdings Inc. announced it intended to file chapter 11 bankruptcy petition. Then the riding on a runaway bull had been started. However, in relation to the fact that the bull market is denoted as market which is being accompanied with stock growth, we should talk about the escape ahead of bears from mountains directly down to the valley or gorge. The fact that crises appear obviously in autumn represents phenomenon which can be investigated in detail. After all, American English use for autumn another term: "fall”. Stock market crash, which got started Great Depression, happened on 29 ${ }^{\text {th }}$ October, 1929 (Black Tuesday). Other famous stock market crash broke up on $19^{\text {th }}$ October, 1987 (Black Monday). Probably, stockbrokers use summer only for relaxing on the beach and when autumn alias fall ask them what did you do in summer, they lost not only memories but also money.

Though what about future. Let me quoted Chance the Gardener from the film Being There (1979): "In the garden, growth has it seasons. First comes spring and summer, but then we have fall and winter. And then we get spring and summer again." We can not go round with movies quotation for very long time. Notwithstanding that Chance the Gardener (acted by Peter Sellers) is simple-minded gardener who is considered to be financial expert, so excellent expert that even the president of the U.S.A. refer to his prediction.

Financial theory must settle many questions. General public is interested mainly in causation of crisis, length of crisis, incidence of crisis and solutions of crisis. However, theory must primarily search into depth of own theoretical conscience. How did financial theory acted before origin of crisis? Was good and fair advisor who warned in face of crisis? Or did it deepened and accelerated crisis by tale about kind market and future success? Or was it neutral and silent observer? By other words it arises question whether financial crisis is not crisis of financial theory? 
Yes, I know. There were bad financial theorists and there were good financial theorists. But why good financial theorists were such discrete? It is not academic question but very top practical. If we can not persuade to world of our usefulness we lost arguments for our existence.

But I can not take a dim view of it. Therefore, let me quote gardener: "after every fall spring is always coming".

\author{
prof. Ing. Petr Marek, CSc. \\ Editorial board's chairman \\ European Financial and Accounting Journal \\ and investigator of the research plan \\ Development of Financial and Accounting Theory and its Application \\ in Practice from Interdisciplinary Point of View
}

